\title{
有機分子素子工学の現状と新展開 液晶界面現象
}

\section{特集解説}

杉 村 明 彦

大阪産業大学

キーワード

ネマティック液晶, ダイレクタ, アンカリング,スメクティック $\mathrm{A}$ 液晶, パターン形成

内 藤 裕 義

大阪府立大学大学院

\section{1. ネマティック液晶の界面現象}

液晶とは、異方性結晶相と等方性相との中閒相を呈す る異方性液体の総称であり、分子配列に長距離秩序度を持 ち、巨視的な光学的・電気的・磁気的・粘性等の異方性を有 する。液晶性を有する物質は、温度上昇に伴い、固体と液体 との中間相で液晶性を示すサーモトロピック液晶と、固体 と等方性液体との溶液状態で液晶性を示すライオトロピッ ク液晶とに分類される。これらの液晶性材料の中で、分子 の重心位置が空間的にランダムで、分子の平均的な配向方 向（ダイレクタ）が揃っているネマティック液晶は、広範 囲な温度領域で液晶相を呈し、多様な電気光学効果を有寸 ることから、最も幅広く研究され、表示素子等八応用され ている。一般にネマティック液晶材料を用いた表示方式は、 数マイクロメートル程度の間隙を有する二枚のガラス基板 間に液晶を封入して使用される。このとき、ガラス基板界 面に配向処理を施すことにより、基板界面近傍でのダイレ クタ配向を決定することができる。すなわち、連続的な弾 性体である液晶性物質の性質から、ガラス基板間バルク内 でのダイレクタ配向分布は、基板界面近傍でのダイレクタ 配向により決定される。さらに、液晶素子に電場を印加す ることにより、バルク内でのダイレクタ配向分布を変化さ せ、素子の光学的異方性を制御することができる。このよ うに、液晶薄膜素子内でのダイレクタ配向分布は、基板界 面でのダイレクタ配向に律則されており、液晶ダイレクタ の界面アンカリング機構の解明と制御は、液晶光電素子一 のデバイス応用に限定されず、ナノメトリック極限領域で の液晶界面物性や、高分子液晶の相変化を含む物理化学現 象を明らかにするための重要な研究課題の一つであり、幅 広く国の内外で、活発な研究が行われている。特に弱い表 面アンカリング条件下での低分子および高分子液晶のダイ ナミクスは、従来の研究に見いだせない新たな物理化学現 象の発現を含むものとして期待されている。

ネマティック液晶のダイレクタ配向機構を調べるために は、液晶を連続体としてとらえた弾性理論が用いられる。 ネマティック液晶の物理的な性質を記述するため、液晶分子 の局所的な平均の配向方向を表すための単位ベクトル、"ダ

Present Status and Future Scope of Organic Molecular and Material Electronics —-Interface Phenomena in Liquid Crystal Slabs-

By Akihiko Sugimura (Osaka Sangyo University) \& Hiroyoshi Naito (Osaka Prefecture University).

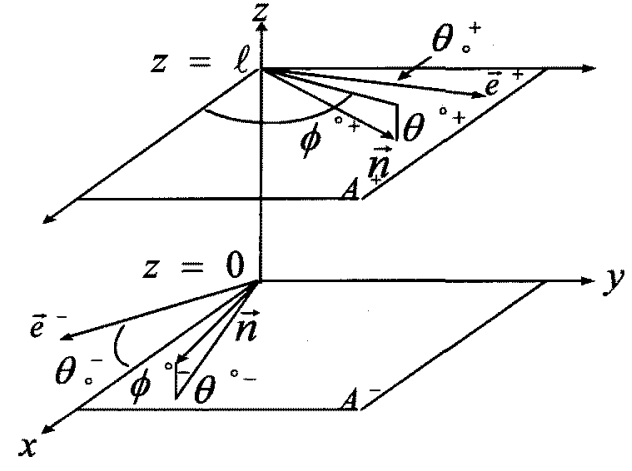

図 1 素子の座標系

イレクタ" $(\vec{n})$ が導入されている(1)。二枚のガラス基板間に 封入された液晶素子の種々の電気光学効果は、このダイレ クタの弹性変形により記述される。素子バルク内でのダイ レクタ弾性変形による過剩な全歪エネルギは、一般に、バ ルクの自由エネルギ密度 $\left(g_{b}\right)$ と二枚の基板表面での表面エ ネルギ密度 $\left(g_{s}\right)$ との和として、次式で表される。

$$
F=\int g_{b} d v+\int g_{s} d s,
$$

ここで、 $g_{b}$ と $g_{s}$ は、それぞれ次式で表される。

$$
\begin{aligned}
g_{b}= & \frac{1}{2}\left[k_{11}(\vec{\nabla} \cdot \vec{n})^{2}+k_{22}\left(\vec{n} \cdot \vec{\nabla} \times \vec{n}+\frac{2 \pi}{p_{0}}\right)^{2}\right. \\
& \left.+k_{33}(\vec{n} \times \vec{\nabla} \times \vec{n})^{2}\right]+g_{f}(\vec{n}), \ldots \ldots \ldots \ldots \ldots \ldots \ldots \ldots \ldots \ldots \ldots
\end{aligned}
$$

ここで、 $k_{11}, k_{22}, k_{33}$ は、スプレイ(splay), ツイスト (twist)，およびベンド(bend) 変形に対する弾性定数で、 $p_{0}$ は、カイラル放をネマティック液晶に混入した場合の螺 旋ピッチを表している。 $g_{f}(\vec{n})$ は、液晶バルクに外部から 印加された電場や磁場のエネルギ密度を示している。液晶 素子一外部電場 $(\vec{E})$ が印加された場合の誘電エネルギは、 $g_{f}=-\left(\varepsilon_{0} \Delta \varepsilon / 2\right)(\vec{n} \cdot \vec{E})^{2}$ で表される。ここで、 $\varepsilon_{0}$ と $\Delta \varepsilon$ は、それぞれ真空の誘電率と液晶材料の誘電率異方性であ る。式(3)は、Rapini と Papoular ${ }^{(2)} に よ り$ 提案された液 
晶と基板表面との現象論的な異方性表面エネルギである。 同式で、 $\mathrm{A}$ は表面エネルギ強度、 $\vec{e}$ は、基板界面でのダイ レクタ配向の容易軸を示す単位ベクトルである。ここで、 表面エネルギ強度とは、基板界面でのダイレクタを容易軸 方向から変位させるのに必要なエネルギ密度として考える ことができる。式 $(1)$ の全自由エネルギの最小化 $(\delta F=0)$ により、液晶素子内でのダイレクタ分布を与える方程式を 得る。いま、図 1 に示す座標系で、 $\mathrm{z}$ 軸方向に素子基板に 垂直な液晶バルク方向を取り $(z=0$ と $z=\ell$ 二枚の基 板表面に取る)、ダイレクタの一次元分布を考える。このと き、ダイレクタは、極角 $(\theta(z))$ と方位角 $(\phi(z))$ を用いて、 $\vec{n}=(\cos \theta \cos \phi, \cos \theta \sin \phi, \sin \theta) 、 \vec{e}=\left(\cos \theta_{0}, 0, \sin \theta_{0}\right)$ で表される。この座標系に対して、一般化した関係式(2)(3) を用い、式(1) を最小化することにより次のバルクおよび 表面でのトルクバランス方程式が求められる ${ }^{(3)}$ 。

$$
\begin{gathered}
f(\theta) \frac{d^{2} \theta}{d z^{2}}+\frac{1}{2} \frac{d f(\theta)}{d \theta}\left(\frac{d \theta}{d z}\right)^{2}-\frac{1}{2} \frac{d h(\theta)}{d \theta}\left(\frac{d \phi}{d z}\right)^{2} \\
+k_{2} \sin 2 \theta \frac{d \phi}{d z}+\frac{\varepsilon_{0} \Delta \varepsilon}{2} E^{2} \sin 2 \theta=0, \\
\frac{d \phi}{d z}=\frac{1}{h(\theta)}\left(C_{1}-k_{2} \cos ^{2} \theta\right), \ldots \ldots \ldots \ldots \ldots \\
\left.f(\theta) \frac{d \theta}{d z}\right|_{z=0}=A\left(\sin \theta_{0} \sin \theta+\cos \theta_{0} \cos \theta \cos \phi\right) \\
\quad \times\left(\cos \theta_{0} \sin \theta \cos \phi-\sin \theta_{0} \cos \theta\right), \cdot \\
\left.h(\theta) \frac{d \phi}{d z}\right|_{z=0}=-k_{2} \cos ^{2} \theta+A\left(\cos \theta_{0} \cos \theta \cos \phi\right. \\
\left.\quad+\sin \theta_{0} \sin \theta\right) \cos \theta_{0} \sin \phi \cos \theta .
\end{gathered}
$$

ここで、 $C_{1}$ は積分定数、 $\theta_{0}$ は $\vec{e}$ 極角を、 $k_{2}=2 \pi k_{22} / p_{0}$ $\left(k_{2}\right.$ の正負の記号は、それぞれ左回り、および右回りの螺 旋を意味する）、 $f(\theta)=k_{11} \cos ^{2} \theta+k_{33} \sin ^{2} \theta 、 h(\phi)=$ $\cos ^{2} \theta\left(k_{22} \cos ^{2} \theta+k_{33} \sin ^{2} \theta\right)$ である。式(4)(5) はバルク 内での、式(6)(7) は基板界面でのトルクバランス方程式で ある。図 1 中で、上下基板界面での物理定数の違いは、+ と一記号の添字を用いて区別している。上下基板界面での物 理定数が異なる場合、界面でのトルクバランス方程式 (6).(7) は、上下基板に対して独立に存在する。与えられた素子基 板表面条件と外部印加電場に対して式 (4)〜 (7) を解くこと により、素子内でのダイレクタ分布を知ることができる。 液晶素子へ外部電場を印加した場合のバルク内ダイレクタ 分布の計算結果例を図 2 に示す。同図は、ダイレクター次 元分布計算結果を基に、楕円でダイレクタを表し、バルク 内配向分布を模式的に表現している。

一般にネマティック液晶材料を用いた表示方式は、液晶 素子基板表面での配向処理による初期ダイレクタ配向分布 を、素子への外部電場印加により変化させ、バルク内での 光学的異方性を制御することにより行われる。すなわち、 バルク内でのダイレクタ分布を正確に制御することにより、 液晶表示特性を決定できる。式(4)〜 (7) は、ダイレクタ分

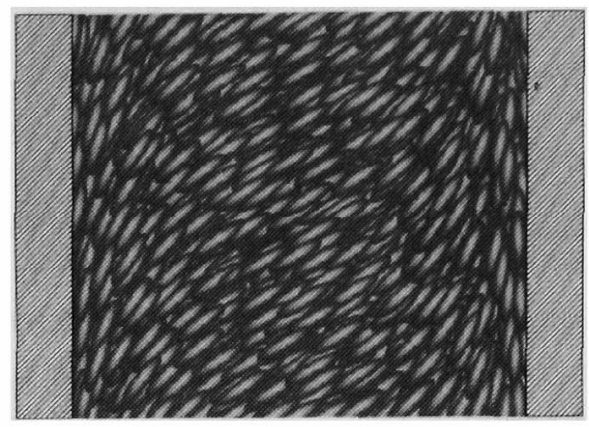

\section{図2 液晶素子内ダイレクタ分布の模式図}

布の静的な分布を与えるが、これらに粘性トルク項を加え ることにより、ダイレクタ分布の時間的な変化を調べるこ とができる。このように、バルク内ダイレクタ分布は、液 晶素子基板界面でのダイレクタ配向、すなおちアンカリン グにより決定される。なお、基板界面でのアンカリング強 度の測定方法としては、強電場法 ${ }^{(4)}$ 、飽和閾值法 ${ }^{(5)}$ 、その 他様々な方法 ${ }^{(6)}$ が用いられている。

ダイレクタ配向分布に関する理論的な取り扱いとともに、 その実験的な検証も重要な問題である。ナノメトリック極 限領域や液晶界面アンカリング機構の解決に向けては、核 磁気共鳴法、ラマン分光法、赤外吸収法、エリプソ分光法等 を用いた液晶分子およびダイレクタレベルでの実験的な研 究が幅広く行われている。核磁気共鳴法は、従来の分子構 造解析や配向度等の物理定数測定に加えて、近年、マイク ロチューブ界面誘起ダイレクタ配向の研究にも用いられて いる。また、重水素化核磁気共鳴法は、単純な共鳴スペクト ルと分子場理論解析から、液晶分子やダイレクタダイナミ クスの実験的研究に有効である(7)。さらに、強磁場に加え て、電場を重複印加した核磁気共鳴法は、界面アンカリン グがバルクでのダイレクタ配向分布に与える効果を調べる ために有効な研究手段であることが報告されている ${ }^{(8)}{ }^{(9)}$ 。 この手法は、一定の強磁場中に設置した液晶セルに電場を 外部印加し、磁場との競合によりダイレクタ回転角を変化 させ、空間的なダイレクタ分布に依存した核磁気共鳴信号 を得ている。このダイレクタ回転は、セル基板界面でのア ンカリング強度、磁気トルク、誘電トルク、弾性トルクに よって決定される。すなわち、核磁気共鳴信号の解析によ り、平均的なセル内ダイレクタ回転角を測定できるだけで なく、ダイレクタ角度分布測定に有効である。

以上、液晶基板界面でのダイレクタ配向機構の理論的・実 験的な取り扱いを、簡単に紹介した。液晶ダイレクタおよ び夜晶分子の巨視的・微視的なアンカリング機構の解明は、 界面での液晶配向機構がバルクへ与える物理化学的な現象 を理解する上で重要な研究課題である。この問題は、ネマ チック液晶だけでなく、液晶性物質全般についても取り組 みが必要であり、今後の研究の進展が期待されている。 


\section{2. スメクティック液晶の界面現象}

液晶物質は分子配列の違いから前述のネマティック液晶、 スメクティック液晶、コレステリック液晶に分類される ${ }^{(1)}$ 。 スメクティック液晶は棒状の液晶分子が層構造を有し、液晶 分子の層内秩序によりさらにスメクティック $\mathrm{A}(\mathrm{Sm}-\mathrm{A}) 、 ス$ メクティック $\mathrm{B} 、 ス メ ク テ ィ ッ ク ~ C$ 相等に分類される ${ }^{(1)}$ 。 のうち Sm-A 相はそのダイレクタ方向が層法線方向にあり、 液晶分子の重心位置の層内秩序はランダムである。等方相 から泠却することにより、この Sm-A 液晶は多様なパター ンを呈する。特に、Sm-A 液晶をシリコンオイルや長鎖ア ルキルアルコールに混合した系では等方相・Sm-A相の共 存相が適当な温度域にわたって観測できる ${ }^{(10)}$ 。Octyloxycyanobiphenyl (8OCB) と dodecyl alcohol (DODA) の混 合系において冷却に伴い現れる典型的なパターンの偏光顕 微鏡による観測結果を図 3 に示す (10) (12)。同図は80CB と DODA 4:6に混合したもので、等方相から $\mathrm{Sm}-\mathrm{A}$ 相・等 方相共存相への相転移温度は約 $40^{\circ} \mathrm{C}$ 、泠却速度は $0.1{ }^{\circ} \mathrm{C} /$ 分である。等方相から泠却すると Sm-A相はまず微少なド ロップレットとして析出し、さらに泠却を進めると、この ドロップレットからシリンダー状のフィラメントが成長す る。このフィラメントはある程度成長すると波打ちはじめ、 顕微鏡視野を埋め尽くすほどのサイズとなる。この後、突 然にかつ急速に凝集をはじめ球状の Sm-A ドメインを形成 する。この様なパターン形成過程の観察とその理論的考察 は単に美しいパターンの形成機構を理解することにとどま らず、以下の重要な意味がある。図 4 は平衡状態、及び非 平衡状態で観察される典型的な $\mathrm{Sm}-\mathrm{A}$ 相の形態で、球、シ リンダー、unduloid、螺旋状の形態を示している。同図に 示した形態は Sm-A 液晶のみならず、生体膜 ${ }^{(13) 、 フ ラ ー レ ~}$ ン類 ${ }^{(14)}$ においても観測されているため、分子(あるいは原 子) の層状構造に由来する普遍性の高い形態であると考えら れる。従がって、Sm-A 液晶のパターン形成機構を解明す ることにより層状構造を有する物質群が示す形態を統一的 に記述する理論を得ることも可能になると期侍できる。こ の様な統一的な理論により、ナノテクノロジーで重要な役 割を果たすフラーレン類の形態制御が可能となり、生体膜 の形態が有する生体機能性が明らかになると期待できる。

$\mathrm{Sm}-\mathrm{A}$ 液晶の形態を明らかにすることが、 $\mathrm{Sm}-\mathrm{A}$ 液晶の形 態が有する (1) 等方相と Sm-A 相のギブスの自由エネルギ 差、(2) 等方相と Sm-A 相の界面エネルギ、(3) 弾性エネル ギの和 $F$ を微分幾何の一般原理を用いた変分計算により第一 変分 $\delta^{(1)} F$ と第二変分 $\delta^{(2)} F$ を求めることで可能となる ${ }^{(15)}$ 。 対象とする形態が閉曲面である場合、曲面の法線方向に変 分を行い(11)、図 3 (b)、(c) に示すような空間曲線の場合、 曲線の主法線と従法線方向に変分を行う ${ }^{(12)}$ 。紙面の都合で 詳細な表式を示すことは控えるが、熱平衡状態にある形態 は $\delta^{(1)} F=0$ の解として与えられ、あわせて、 $\delta^{(2)} F>0$ を 満たしている必要がある。また、等方相からの泠却過程な どの非平衡状態では $\delta^{(1)} F=0$ のみで形態を議論すること

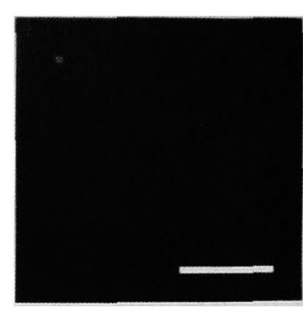

(a)

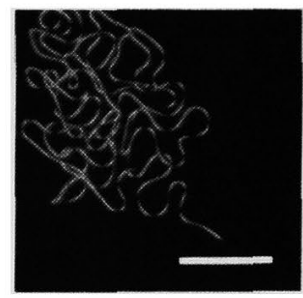

(c)

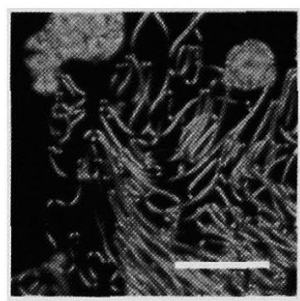

(e)

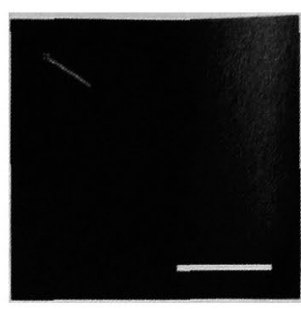

(b)

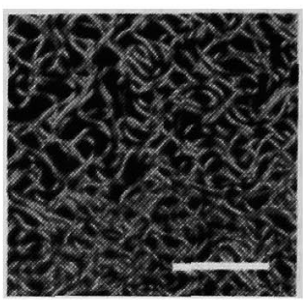

(d)

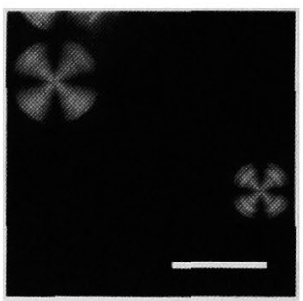

(f)
図 3 等方相中の Sm-A 相の成長過程。図中の白線は $50 \mu m$ である。
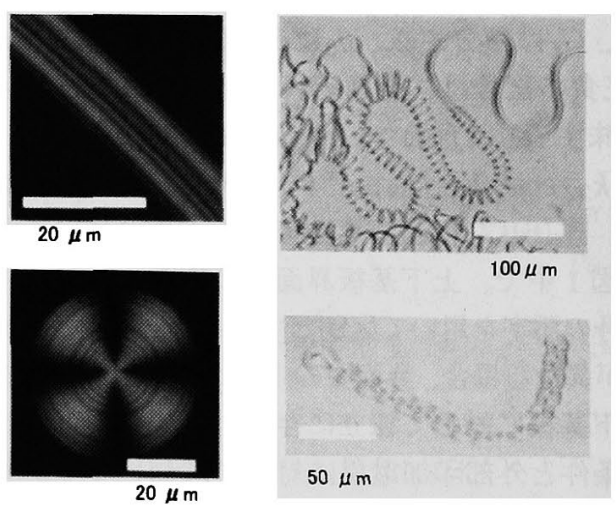

図 4 等方相中のSm-A 相が示す典型的な形態。

ができる。図4に示した形態はすべてこの様な理論により 説明可能である。なお、Sm-A 相が呈する形態は等方相と $\mathrm{Sm}-\mathrm{A}$ 相の界面エネルギによる影響を強く受ける。

生体膜、フラーレンでも同様な理論的取り扱いが可能で ある。生体膜は脂質二分子膜により細胞の内部と外部が隔 てられていて、この脂質二分子膜は液晶相 $\left(L_{\alpha}\right.$ 相 $)$ にあり脂 質のダイレクタ方向は層法線方向にある。実際、ある条件 
の下では Sm-A 相における変分計算の結果は生体膜におけ る変分計算の結果である Helfrich-Ou-Yang の形態方程式 （一般化された Laplaceの式）と一致する ${ }^{(11)}$ 。この形態方 程式により赤血球形態の説明がなされ、従来裏打ち蛋白に より赤血球形態が保持されていると考えられていたが、こ の形態は脂質二分子膜の弾性的な性質のみから生じること を示すことができた ${ }^{(16)}$ 。また、フラーレンの場合でもフ ラーレンの凝集過程が $\mathrm{Sm}-\mathrm{A}$ 液晶と類似であることから、 $\mathrm{Sm}-\mathrm{A}$ 相における変分計算の結果を直接用いることができ、 様々な形態の存在が説明可能である ${ }^{(17) 。}$

一方、この様な等方相中のスメクティック $\mathrm{A}$ 相の形態を 利用した光デバイス応用の可能性もある。例えば、図 5 (a) に示す真球状ドメインに電界印加することにより生じる微 小球 $($ 図 $5(b))$ を波長可変レーザに応用する試みである。電 界印加により真球状ドメインは数多くの微小球ドメインに 分裂するが、これら微小球のサイズは印加電界により制御 することが出来る。なお、この過程も上述の理論によって説 明可能である。微小球による光の閉じ込めは古くから知ら れていたが、それがレーザキャビティーとして機能するこ とが示されたのはごく最近のことである。この微小球レー ザは共振器が数十ミクロンと微小でありながら極めて高い Q值を有し、低しきい值レーザや低パワー光スイッチ素子 への応用上きわめて有利である。さらに、レーザ発振波長 は微小球のサイズに敏感に依存するため、印加電界と微小 球径の関係より波長可変微小球レーザを構築することがで きる。

以上、等方相 $-\mathrm{Sm}-\mathrm{A}$ 相界面現象に起因する $\mathrm{Sm}-\mathrm{A}$ 液晶 の形態形成を実験、理論両面から簡単に述べた。 $\mathrm{Sm}-\mathrm{A}$ 液 晶の形態形成は分子配列秩序が層状構造を有する生体膜や フラーレン類などと共通の機構で説明することができ、こ れら物質群の形態形成を統一的に行うことが可能になって きている。また、 Sm-A 液晶の形態形成は電界により制御 することができ、微小球レーザへの展開が可能である。こ の様に $\mathrm{Sm}-\mathrm{A}$ 液晶の形態形成は物理的のみならず応用上も 重要で、今後更なる研究展開が望まれる。

本研究の一部は科学研究費補助金 (13875063)、住友財団、 池谷財団の援助による。

(平成 13 年 5 月 7 日受付)

\section{文献}

(1) P. G. de Gennes, The Physics of Liquid Crystals, (Oxford University, London, 1974).

(2) A. Rapini and M. Papoular, J. Phys. (Paris) Colloq. 30, C4-54 (1969).

(3) A. Sugimura, G. R. Luckhurst and Z. Ou-Yang, Phys. Rev. E, 52, 681 (1995)

(4) A. Sugimura, T. Miyamoto, M. Tsuji, and M. Kuze, Appl. Phys. Lett. 72, 329 (1998).

(5) H. Yokoyama and H. A. van Sprang, J. Appl. Phys. 57, 4520 (1985).

(6) A. A. Sonin, The Surface Physics of Liquid Crystals, (Gordon and Breach, 1995).

(7) see for example, NMR of Liquid Crystals, ed. J. W. Emsley

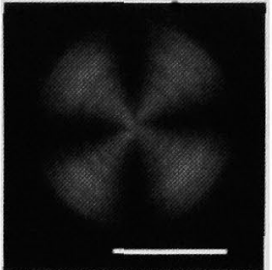

(a)

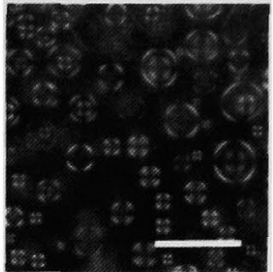

(b)

図 5 等方相中に成長した Sm-A 相ドメインの偏光 顕微鏡像。図中の白線は $50 \mu m$ である。左図は電界を 印加しない場合の Sm-A 相の具球状ドメイン、右図 は $1 V / \mu m$ の電界印加により複数の微小球に分裂した Sm-A 相ドメインである。

(Reidel, Dordrecht, 1985).

(8) G. R. Luckhurst, A. Sugimura, and B. A. Timimi, Mol. Cryst. Liq. Cryst. 347, 53 (2000).

(9) G. R. Luckhurst, T. Miyamoto, A. Sugimura, T. Takashiro and B. A. Timimi, J. Chem. Phys. to be published in an issue of 15 th of June, (2001).

(10) R. Pratibha and N. V. Madhusudana, J. Phys. (France) II 2, 383 (1992)

(11) H. Naito, M. Okuda, and Z. Ou-Yang, Phys. Rev. E 52, 2095 (1995).

(12) H. Naito, M. Okuda, and Z. Ou-Yang, Phys. Rev. E 55, 1655 (1997).

(13) Z. Ou-Yang, J. Liu and Y. Xie, "Geometric Methods in the Elastic Theory of Membranes in Liquid Crystal Phases" (World Scientific, Singapore, 1999).

(14) S. S. Xie, W. Z. Li, L. X. Qian, B. H. Chang, C. S. Fu, R. A. Zhao, W. Y. Zhou, and G. Wang, Phys. Rev. B 54, 16436 (1996).

(15) H. Naito, M. Okuda, and Z. Ou-Yang, Phys. Rev. Lett. 70, 2912 (1993).

(16) H. Naito, M. Okuda, and Z. Ou-Yang, Phys. Rev. E 48, 2304 (1993).

(17) Z. Ou-Yang, S. Zhao-Bin, and W. Chui-Lin, Phys. Rev. Lett. 78,4055 (1997).

（非会員） 1951 年 12 月 16 日生。1981 年 3 月大阪 府立大学大学院工学研究科博士課程単位取得退学。

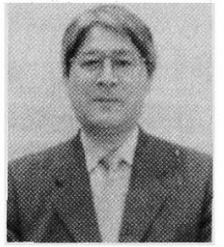
1981 年 4 月大阪府立大学助手、1987年近畿大学 助手、1990年大阪産業大学助教授を経て、1996 年 4 月教授。現在に至る。1994 1995 年サザンプ トン大学客員研究員。主として、ネマチック液晶 の電気光学効果とダイレクタ配向過程に関する研 究に従事。日本液晶学会、応用物理学会、電子情 報通信学会、米国物理学会、各会員。

内 藤 裕

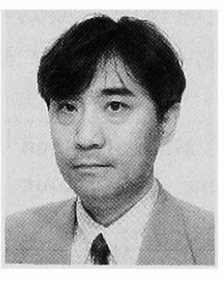

際液晶学会各会員。

（非会員）昭和 54 年大阪府立大学工学部電気工学 科卒業。昭和 59 年同大学院博士課程修了。同年 大阪府立大学工学部助手。平成 12 年同教授。現在 に至る。この間、平成 4 年、ケンブリッジ大学客 員研究員。有機半導体の光電物性、液晶のパター ン形成等の研究に従事。平成 12 年日本液晶学会 論文賞受賞。電子情報通信学会、応用物理学会、 日本物理学会、日本液晶学会、米国物理学会、国 